\title{
Hubungan Dukungan Emosional Keluarga dengan Keberhasilan Pelaksanaan Program Pengobatan HIV/AIDS di Rumah Sakit Penyakit Infeksi (RSPI) Prof. Dr. Sulianti Saroso
}

\author{
Relationship Emotional Family Support with Implementation The Treatment \\ Program HIV/AIDS in Infectious Disease Hospital Prof. Dr. Sulianti Saroso
}

\author{
Maulia Hindun Audhah ${ }^{1^{\star}}$, Marisca Agustina ${ }^{2}$ \\ ${ }^{1}$ RSPI Prof.DR.Sulianti Saroso Jakarta \\ ${ }^{2}$ Sekolah Tinggi IImu Kesehatan Indonesia Maju
}

${ }^{*}$ Korespondensi Penulis:

Maulia Hindun Audhah

Email : mauliahindun@yahoo.com

\begin{abstract}
Abstrak
Latar belakang : Dukungan emosional keluarga merupakan salah satu aspek dukungan keluarga yaitu suatu bentuk kenyamanan, perhatian ataupun bantuan yang diterima individu dari orang yang berarti baik secara perorangan maupun kelompok. Tujuan penelitian ini untuk mengidentifikasi hubungan dukungan emosional keluarga dengan pelaksanaan program pengobatan pasien HIV/AIDS.

Metode : Desain dalam penelitian ini adalah deskriptif korelasional dengan pendekatan cross sectional. Sample dalam penelitian ini adalah pasien HIV/AIDS yang melakukan pengobatan dipokja HIV/AIDS RSPI Prof. Dr. Sulianti Saroso sebanyak 98 pasien yang diambil dengan teknik purposive sampling. Data di analisis secara univariat dan bivariat dengan uji Chi Square.

Hasil : Dari 98 responden sebagian besar yaitu 54 (54,1\%) menyatakan kurang mendapatkan dukungan emosional keluarga dan $53(53.1 \%)$ tidak rutin dalam pelaksanaan program pengobatan pasien HIV/AIDS. Ada hubungan yang signifikan antara dukungan emosional keluarga dengan kepatuhan program pengobatan HIV/AIDS (PValue = 0,01).

Kesimpulan : Ada hubungan antara dukungan emosional keluarga dengan kepatuhan program pengobatan HIV/AIDS.
\end{abstract}

Kata Kunci: Dukungan emosional keluarga, Pengobatan pasien HIV/AIDS

\begin{abstract}
Background : Emotional support is one of family's support aspect and a form of comfort, care and help that received by a person from someone important for them. The purpose of this research is to identified the correlation of emotional support and the implementation of HIV treatment programs.

Methods: The design of this research is descriptive correlation with cross sectional approach. The amount of samples is 98 patien with HIVIAIDS from pokja-HIVIAIDS at RSPI Prof. Dr. Sulianti Saroso. Data analysis consist of univariate and bivariate analysis with chi square test .

Results : Of the 98 respondents most of which 54 (54.1\%) expressed less get emotional family support and $53(53.1 \%)$ is not routine in the implementation of the treatment of patients with HIV/AIDS. There was a significant correlation between emotional support families with the compliance program HIVIAIDS treatment ( Pvalue $=0,01$ ).

Conclusion : There is a significant correlation between emotional support and the adherence of HIV treatment.
\end{abstract}

Keywords: Emotional family support, HIVIAIDS treatment program 


\section{Pendahuluan}

HIV/AIDS merupakan masalah kesehatan yang mengancam Indonesia dan banyak negara di seluruh dunia dengan jumlah orang yang terinfeksi HIV terus meningkat pesat dan tersebar luas di seluruh dunia., ${ }^{1,2}$

Di dunia tercatat jumlah penderita HIV/AIDS 35,3 juta orang pada tahun 2012, dengan penderita dewasa 32,1 juta, wanita 17,7 juta dan anak < 15 tahun sebanyak 3,3 juta. Dengan karakteristik jumlah penderita yang baru terinfeksi HIV/AIDS pada tahun 2012 sebanyak 2,3 juta jiwa dan yang mengalami kematian ditahun 2012 sebanyak 1,6 juta jiwa. Kasus HIVAIDS di Indonesia pertama kali ditemukan pada tahun 1987 di Bali. Sejak saat itu, jumlah kasus HIV/AIDS di Indonesia meningkat setiap tahunnya. Pada tahun 2013 dilaporkan jumlah penderita HIV sebanyak 20413 jiwa sedangkan penderita AIDS 2763 jiwa. Data tersebut diyakini masih jauh dari jumlah sebenarnya dan masih akan terus meningkat. Kelompok terbesar penderita HIV/AIDS berusia produktif diantara 20 - 39 tahun yaitu sekitar 88,4 \% dari keseluruhan penderita HIV/AIDS sedangkan sisanya $11,6 \%$ adalah usia tidak produktif., ${ }^{3,4}$

Permasalahan medis yang dihadapi ODHA dapat berupa infeksi oportunistik, gejala simtomatik yang berhubungan dengan AIDS, koinfeksi, sindrom pemulihan kekebalan tubuh serta efek samping dan interaksi obat ARV. Sedangkan masalah psikologis yang mungkin timbul yang berkaitan dengan infeksi HIV/AIDS adalah depresi, ansietas, gangguan kognitif serta gangguan kepribadian sampai psikosis. Seseorang yang menjalani pengobatan atau menghadapi prosedur medis di Rumah Sakit memerlukan dukungan. Dukungan ini diperoleh dari berbagai macam sumber misalnya pasangan hidup, orang tua, keluarga, kakek, nenek, anak, teman, rekan kerja, tenaga kesehatan dan sebagainya. Menurut Sarafino dukungan adalah suatu bentuk kenyamanan, perhatian, penghargaan ataupun bantuan yang diterima individu dari orang yang berarti baik secara perorangan maupun kelompok. . $^{5,6}$

Pentingnya dukungan emosional keluarga, maka setiap anggota keluarga akan dapat mewujudkan hidup yang lebih baik, sekaligus juga dapat membantu pencapain keberhasilan program pengobatan, yaitu dengan memberikan dukungan emosional keluarga berupa pemberian perhatian, ungkapan rasa empati, penghargaan, kasih sayang dan kenyaman dalam hubungan personal. Penelitian yang spesifik membahas dukungan emosional keluarga pada pasien 
HIV/AIDS belum banyak dilakukan di Indonesia sehingga penulis tertarik melakukan penelitian tersebut.

Tujuan penelitian ini adalah untuk mengetahui hubungan emosional keluarga dengan pelaksanaan program pengobatan pada pasien HIV/AIDS di Rumah Sakit Penyakit Infeksi Prof. Dr. Sulianti Saroso Jakarta tahun 2014.

\section{Metode}

Penelitian ini merupakan penelitian deskriptif korelasional dengan pendekatan cross sectional. Populasi dalam penelitian ini adalah pasien HIV-AIDS yang melakukan pengobatan di Pokja HIV/AIDS RSPI Prof. DR. Sulianti Saroso sebanyak 4600 penderita persatu semester dari bulan Juni-Desember 2013. Dari hasil perhitungan sampel menggunakan rumus solvin dengan presisi $10 \%$ diperoleh sampel sebanyak 98 pasien yang menjalani program pengobatan HIV/AIDS di Pokja HIV/AIDS RSPI Prof. Dr. Sulianti Saroso Jakarta yang diambil dengan teknik purposive sampling.

Dukungan emosional keluarga diukur menggunakan kuesioner yang dibuat oleh peneliti yang meliputi indikator kebersamaan, pemberian perhatian, kasih sayang, penghargaan, ungkapan rasa simpati. Kuesioner dukungan emsoional keluarga yang digunakan dalam penelitian ini adalah kuesioner tertutup dengan jumlah 20 pertanyaan dalam bentuk skala likert. Kuesioner dukungan emosional keluarga yang digunakan telah diuji validitas dan relibialitasnya. Pelaksanaan pengobatan HIV/AIDS didasarkan pada keteraturan pengobatan yaitu sebulan sekali atau sesuai instruksi tenaga kesehatan.

Analisa data dalam penelitian ini meliputi univariate dan bivariat dengan uji chi square dengan tingkat kemaknaan $95 \%$ menggunakan bantuan software SPSS versi 20 for windows. Penelitian ini telah mendapatkan keterangan lolos kaji etik dari Komite Etik Rumah Sakit Penyakit Infeksi Prof. Dr. Sulianti Saroso Jakarta.

\section{Hasil}

Karakteristik pasien HIV/AIDS di Pokja HIV-AIDS RSPI Pror. Dr. Sulianti Saroso sebagian besar pasien HIV/AIDS berusia 30-39 Tahun (usia produktif) yaitu 45 (45,9\%), berjenis kelamin laki-laki yaitu 63 (64,3\%), berpendidikan SMA yaitu 52 (53,5\%), bekerja yaitu $82(83,7 \%)$ dan dengan lama pengobatan < 1 tahun yaitu 46 (45,9\%). Hasil disajikan pada tabel 1. 
Tabel 1. Karakteristik Pasien HIV/AIDS di Pokja HIV-AIDS RSPI Prof. Dr. Sulianti Saroso

\begin{tabular}{clcc}
\hline No & \multicolumn{1}{c}{ Variabel } & $\mathrm{f}$ & $\%$ \\
\hline 1 & Umur & & \\
& $<20$ Tahun & 1 & 1 \\
& 20-29 Tahun & 28 & 26 \\
& 30-39 Tahun & 45 & 45,9 \\
& 40-49 Tahun & 16 & 16,3 \\
& > 50 Tahun & 8 & 8,2 \\
& Jumlah & 98 & 100,0 \\
\hline 2 & Jenis Kelamin & & \\
& Laki-laki & 63 & 64,3 \\
& Perempuan & 35 & 35,7 \\
& Jumlah & 98 & 100,0 \\
\hline 3 & Pendidikan & & \\
& SD & 9 & 9,2 \\
& SMP & 26 & 26,5 \\
& SMA & 52 & 53,5 \\
& Diploma/PT & 11 & 11,2 \\
& Jumlah & 98 & 100,0 \\
\hline 4 & Pekerjaan & & \\
& Bekerja & 82 & 83,7 \\
& Tidak Bekerja & 16 & 16,3 \\
& Jumlah & 98 & 100,0 \\
\hline 5 & Lama Pengobatan & & \\
& < 1 Tahun & 46 & 45,9 \\
& 1-5 Tahun & 35 & 35,7 \\
& > 5 Tahun & 17 & 17,3 \\
& Jumlah & 98 & 100,0 \\
\hline & & &
\end{tabular}

Hasil penelitian diketahui sebagian besar pasien HIV/AIDS menyatakan kurang mendapatkan dukungan emosional keluarga yaitu 54 pasien $(54.1 \%)$ dan melaksanakan pengobatan secara tidak rutin yaitu sebanyak 53 orang (53,1\%). Hasil disajikan pada tabel 2 .

Analisis antara dukungan emosional keluarga dengan pelaksanaan program pengobatan HIV/AIDS diketahui bahwa dari 45 responden yang menyatakan mendapatkan dukungan emosional dari keluarga sebagian besar yaitu 28
$(62.2 \%)$ melaksanakan program pengobatan HIV secara rutin. Dari 53 responden yang menyatakan bahwa tidak mendapat dukungan emosional dari keluarga sebagian besar yaitu 35 $(66.0 \%)$ tidak melaksanakan program pengobatan secara rutin. Hasil analisis dengan chi square diperoleh Pvalue $=0.01$ (< alpha 5\%), maka dapat diambil kesimpulan bahwa terdapat hubungan dukungan emosional keluarga dengan pelaksanaan program pengobatan pada pasien HIV/AIDS di Poli Pokja HIV/AIDS Rumah Sakit Penyakit Infeksi Prof. Dr Sulianti Saroso tahun 2014 dengan nilai peluang POR $=3,203(95 \% \mathrm{Cl}:$ 1,3997.333) artinya responden yang mendapatkan dukungan keluarga berpeluang 3 kali lebih besar untuk melaksanakan program pengobatan HIV-AIDS secara rutin dibandingkan yang tidak mendapatkan dukungan emosional dari keluarga (Tabel 3).

Tabel 2. Dukungan Emosional Keluarga dan Pelaksanaan Program Pengobatan Pasien HIV/AIDS di Pokja HIV/AIDS RSPI Prof. Dr. Sulianti Saroso

\begin{tabular}{lcc}
\hline Variabel & $f$ & $\%$ \\
\hline $\begin{array}{l}\text { Dukungan Emosional } \\
\text { Keluarga }\end{array}$ & & \\
- Mendukung & 45 & 45,9 \\
- Tidak Mendukung & 54 & 54,1 \\
\hline $\begin{array}{l}\text { Pelaksanaan Program } \\
\text { Pengobatan }\end{array}$ & & \\
- Rutin & 46 & 46,9 \\
Tidak rutin & 53 & 53,1 \\
\hline
\end{tabular}


Tabel 3. Hubungan antara Dukungan Emosional Keluarga dengan Pelaksanaan Program Pengobatan Pasien HIV/AIDS di Pokja HIV/AIDS RSPI Prof.Dr. Sulianti Saroso

\begin{tabular}{ccccccccc}
\hline \multirow{2}{*}{$\begin{array}{c}\text { Dukungan Emosional } \\
\text { Keluarga }\end{array}$} & \multicolumn{3}{c}{ Pelaksanaan Pengobatan } & \multicolumn{2}{c}{ Total } & \multirow{2}{*}{ P -value } \\
\cline { 2 - 6 } & \multicolumn{2}{c}{ Rutin } & $\%$ & $\mathrm{n}$ & $\%$ & $\mathrm{n}$ & $\%$ & \\
\cline { 2 - 7 } & 28 & 62.2 & 17 & 37.8 & 45 & 100 & 0.01 \\
\hline \hline Mendukung & 18 & 34.0 & 35 & 66.0 & 53 & 100 & \\
Kurang Mendukung & 46 & 46.9 & 52 & 53.1 & 98 & 100 & \\
\hline Jumlah & & & & & & &
\end{tabular}

\section{Pembahasan}

Program pengobatan HIV-AIDS merupakan program yang akan dilakukan seumur hidup,banyak penderita HIV/AIDS. Hasil analisis diketahui bahwa ada hubungan yang signifikan antara dukungan emosional keluarga dengan pelaksanaan program pengobatan HIV/AIDS di poli Pokja HIV/AIDS RSPI Prof. Dr. Sulianti Saroso Jakarta. Penelitian ini sejalan dengan penelitian Roy Richad Siahaan (2011) yang berjudul meneliti tentang dukungan keluarga terhadap program pengobatan pasien HIV/AIDS di kota Medan yang menatakan bahwa ada hubungan dukungan emosioanal terhadap program pengobatan (nilai $P=0,003)^{7}$

Secara teori pada individu yang mengalami HIV/AIDS positif, salah satu cara untuk meningkatkan sistem imunitas atau untuk menghambat perkembangan virus HIV adalah dengan program pengobatan.
Persyaratan dalam menjalankan program pengobatan HIV/AIDS pada saat pasien datang ke rumah sakit melakukan konseling pra ARV dan penerimaan obat $A R V$, melakukan foto thoraks, melakukan kontrol 2 minggu pertama pengobatan, 1 bulan setelah 6 bulan pengobatan, tes CD4 dalam 6 bulan (normal 400-1500) dan kepatuhan minum obat dengan terlebih dahulu melakukan konseling adherence/ kepatuhan minum obat. ${ }^{5,8}$

Dukungan keluarga dapat membantu pasien mengatasi masalah dan mendefinisikan kembali situasi tersebut sebagai ancaman kecil dan keluarga bertindak sebagai pembimbing dengan memberikan umpan balik dan mampu membangun harga diri pasien. Dalam sebuah unit keluarga disfungsi dan gangguan akan mempengaruhi satu atau lebih anggota keluarga yang lain dan dalam hal tertentu sering mempengaruhi keluarga ini sebagai unit secara keseluruhan. 
Hal ini dimungkinkan karena adanya semacam hubungan yang kuat antara keluarga dan status kesehatan anggotanya. Melalui perawatan kesehatan keluarga yang berfokus pada tindakan promotif, peningkatan self care, pendidikan kesehatan, dan konseling keluarga serta upaya-upaya yang berarti dapat mengurangi resiko yang diciptakan oleh pola hidup dan bahaya dari lingkungan. ${ }^{9}$

Pada individu dengan HIV positif sistem imunitasnya akan mengalami penurunan dan membutuhkan waktu beberapa tahun hingga ditemukannya gejala tahap lanjut dan dinyatakan sebagai penderita AIDS. Hal ini tergantung pada kondisi fisik dan psikologisnya. Sejak dinyatakan terinfeksi HIV penderita mengalami stres dikarenakan tingginya tekanan psikososial yang mereka terima baik dari keluarga maupun masyarakat. Oleh karena itu dukungan emosional terutama dari keluarga penting artinya, dan sangat menentukan perkembangan penyakit yang berdampak pada ketiga aspek dalam respons sosial (emosional) pasien HIV/AIDS. Bila hal ini tidak segera diatasi maka dapat menurunkan kondisi kesehatan pasien, mempercepat progresivitas penyakit hingga timbulnya kematian. ${ }^{10}$
Dukungan emosional yang diberikan keluarga kepada penderita akan mendorong penderita untuk dapat menjalani perawatan secara teratur, hal ini dikarenakan dukungan yang diberikan tersebut dijadikan sebagai energi penggerak bagi penderita dalam menjalankan suatu program terapi. ${ }^{6}$

Dukungan emosional keluarga berhubungan dengan pelaksanaan program pengobatan HIV/AIDS. Sehingga diharapkan Pokja agar melakukan kegiatan yang melibatkan pasien dan keluarga, Profesi tenaga kesehatan khususnya tenaga keperawatan sebagai edukator, motivator dan conselor dalam memberikan penyuluhan untuk mensukseskan program pengobatan pasien HIV/AIDS.

\section{Kesimpulan}

Pasien HIV/AIDS di Pokja HIV/AIDS RSPI Prof. Dr. Sulianti Saroso sebagian besar menyatakan kurang mendapatkan dukungan emosional keluarga dan melaksanakan pengobatan secara tidak rutin. Terdapat hubungan dukungan emosional keluarga dengan pelaksanaan program pengobatan pada pasien HIV/AIDS di Poli Pokja HIV/AIDS. 


\section{Ucapan Terima Kasih}

Penulis mengucapkan terima kasih kepada institusi RSPI Prof Dr. Sulianti Saroso dan semua pihak yang terlibat dalam proses pengumpulan data dan analisa data.

\section{Daftar Pustaka}

1. Zein, Umar, dkk.,100 Pertanyaan Seputar HIV/AIDS Yang Perlu Anda Ketahui. Medan: USU press; 2006.

2. Ashari, Muhammad Dedi. Hindari AIDS Demi Masa Depan Kita Semua.Dalam: Nasution, Rizali $\mathrm{H}$, dkk., ed. AIDS: Kita Bisa Kena, Kita Bisa Cegah. Medan: Monora; 2000.

3. Desmawati. Sistem Hematologi \& imunologi. Jakarta : In Media;2013.

4. Direktoral Jendral Pengendalian Penyakit Menular \& Penyehatan Lingkungan. (2012). Statistik kasus HIV/AIDS Jakarta : Depkes;2012.

5. Direktoral Jendral Pengendalian Penyakit Menular \& Penyehatan Lingkungan. Pedoman tatalaksana klinis infeksi HIV disarana pelayanan kesehatan. Jakarta : Depkes;2007.

6. Sarafino, E.P. Health Psychology : Biopsychosocial Interactions. Fifth Edition.USA : John Wiley \& Sons;2006.

7. Roy, Richard, S. Pengaruh Dukungan Keluarga Terhadap Program Pengobatan PAsien HIVAIDS Di Ponyasus Rumah Sakit Umum Pusat Haji Adam Malik Medan. Skripsi. STIKes Mutiara Indonesia Medan; 2011.
8. Burgoyne, R. W. Menjelajahi arah sebab-akibat antara dukungan social dan hasil klinis untuk HIV positif dewasa dalam konteks terapi antiretroviral yang sangat aktif Peduli AIDS;2005. Available from: com $/ 10.1007 \%$ 2Fs 10461 006.

9. Payuk. (2012). Hubungan dukungan social dengan kualitas hidup orang dengan HIV/AIDS di Puskesmas Jumpandang Makasar. Diakses tanggal 26 Februari 2014. http: //spritia.or.id.

10. Sudoyo W, Aru. Buku Ajar IImu Penyakit Dalam. Edisi 5, Jakarta : Internal Publishing; 2010. 